\title{
Keeping the land: indigenous communities' struggle over land use and sustainable forest management in Kalimantan, Indonesia
}

\author{
$\underline{\text { Elizabeth Linda Yuliani }}^{1,2}, \underline{\text { Edwin B. P. de Jong }}{ }^{3}$, Luuk Knippenberg $^{2,3}$, Denny O. Bakara $^{4}$, Mohammad Agus Salim $^{1}$ and Terry \\ Sunderland $^{1,5}$
}

\begin{abstract}
Despite the great emphasis on sustainable forest management in the 1998 Indonesian reform movement, deforestation has only accelerated since then, with Kalimantan (Indonesian Borneo) exhibiting the highest rate of forest loss. Some forested areas have, however, been preserved by local communities. We investigate how and why two of these communities in Kapuas Hulu district, West Kalimantan, have managed to maintain their forests against the pressures of illegal logging and conversion to oil palm plantations. One village community had the capacity to act on its own, while the other needed additional capacity through intercommunity collaboration. Motivations behind these villages' decisions were both economic and eudaimonic; their desire for meaningful lives related to the community and environment and to past and future generations. The findings enrich the literature on land use change because description and analysis of successful resistance against logging and oil palm is still rare. As such, the findings offer a different way to understand and interrogate the challenges confronting present-day forest communities in Kalimantan and beyond, standing out against the mainstream impression that communities are still powerless or unwilling to resist the short-term economic lures. We also refer briefly to the environmental justice perspective.
\end{abstract}

Key Words: communal property; communal resistance; eudaimonia; forest and deforestation; Indonesia; logging; motivation and capacity; oil palm; sustainable forest management

\section{INTRODUCTION}

Sustainable and equitable natural resource management became one of the most important issues in Indonesia's 1998 reform movement and in subsequent decentralization regulations. However, Indonesia's deforestation rate has been accelerating since early 2000 (FWI 2011, Margono et al. 2014), mainly as a result of rapid political and institutional changes, micropolitical actions among elites, broker practices, and the government's priority of increasing district revenues through large-scale investment (Smith et al. 2003, Wadley and Eilenberg 2005, Barr et al. 2006, Eilenberg 2012). Depending on the nature and location of the land, decentralization regulations allow governors and district heads to grant sizeable concessions and permits to companies for forest resource extraction (Government of Indonesia 1999) and/or plantation development (Ministry of Agriculture of Indonesia 2013). Furthermore, Law no. 18/2004 on plantations (Government of Indonesia 2004) requires that a plantation planned on customary land needs approval from the customary right holders, as well as agreement on the conditions of the land transfer and the amount and nature of the compensation set (see for more details Yuliani et al. 2010). Although such regulations were aimed to improve indigenous people's livelihoods, there are numerous accounts that point to opposite results (e.g., McCarthy and Cramb 2009, Sheil et al. 2009).

In Kalimantan (Indonesian Borneo), the lifting of Indonesia's export ban on logs in 1998 rapidly increased logging activities to meet the heavy demand for wood just across the border in Malaysia (Obidzinski 2005). After logging slowed down by mid-2000, large-scale plantation development became the major cause of deforestation. Subsequently, Kalimantan experienced the highest deforestation rate in the country, with approximately $55,000 \mathrm{~km}^{2}$ of forest lost between 2000 and 2009 (FWI 2011).

This situation is contrary to the democracy, equity, and sustainability goals underlying the Indonesian reform movement, representing what Schmink and Wood (1992) label an "ironic twist." It reflects what Rudel and Roper (1997) call the frontier model, i.e., occurring in places with large forest areas, being capital-driven, and involving encounters between competing social-cultural, socioeconomic, and economic-ecological practices, discourses, and traditions. These frontiers could become new commodity forms and reconstitute the relationships between capital, society, and state authorities (Kelly and Peluso 2015). Therefore, perspectives on frontiers should be enriched and broadened (De Jong et al. 2017).

We focus on two communities that represent those who have been able to preserve their forests, and investigate how they responded to the two major challenges: commercial logging and the (further) development of industrial oil palm plantations. Our two research questions are descriptive and explanatory in nature: "How did the case study communities manage to preserve their forest in the face of logging and oil palm?" and "Why did it happen that way?"

\section{BACKGROUND AND STUDY AREA}

Research took place in Kapuas Hulu district, which is situated in West Kalimantan, covering an area of $31,000 \mathrm{~km}^{2}$. The total population of approximately 250,000 people generally belong to the two dominant ethnic groups of the area: the Iban Dayak and Malay (Kapuas Hulu Statistics 2017). The district's forest and wetland ecosystems have key hydrological functions for Indonesia's longest river, the Kapuas (Klepper 1994). The Kapuas river is $1143 \mathrm{~km}$ in length and supportive for the livelihoods of

${ }^{1}$ Center for International Forestry Research (CIFOR), ${ }^{2}$ Institute for Science in Society, Radboud University Nijmegen, ${ }^{3}$ Department of Anthropology and Development Studies, Radboud University Nijmegen, ${ }^{4}$ Riak Bumi Foundation, ${ }^{5}$ Department of Forest and Conservation Science, University of British Columbia, Canada 
Fig. 1. Deforestation between 2001 and 2014 in the northwestern part of Kapuas Hulu district. Map by: M. A. Salim, CIFOR. Source of data: Hansen et al. 2013, Margono et al. 2014.

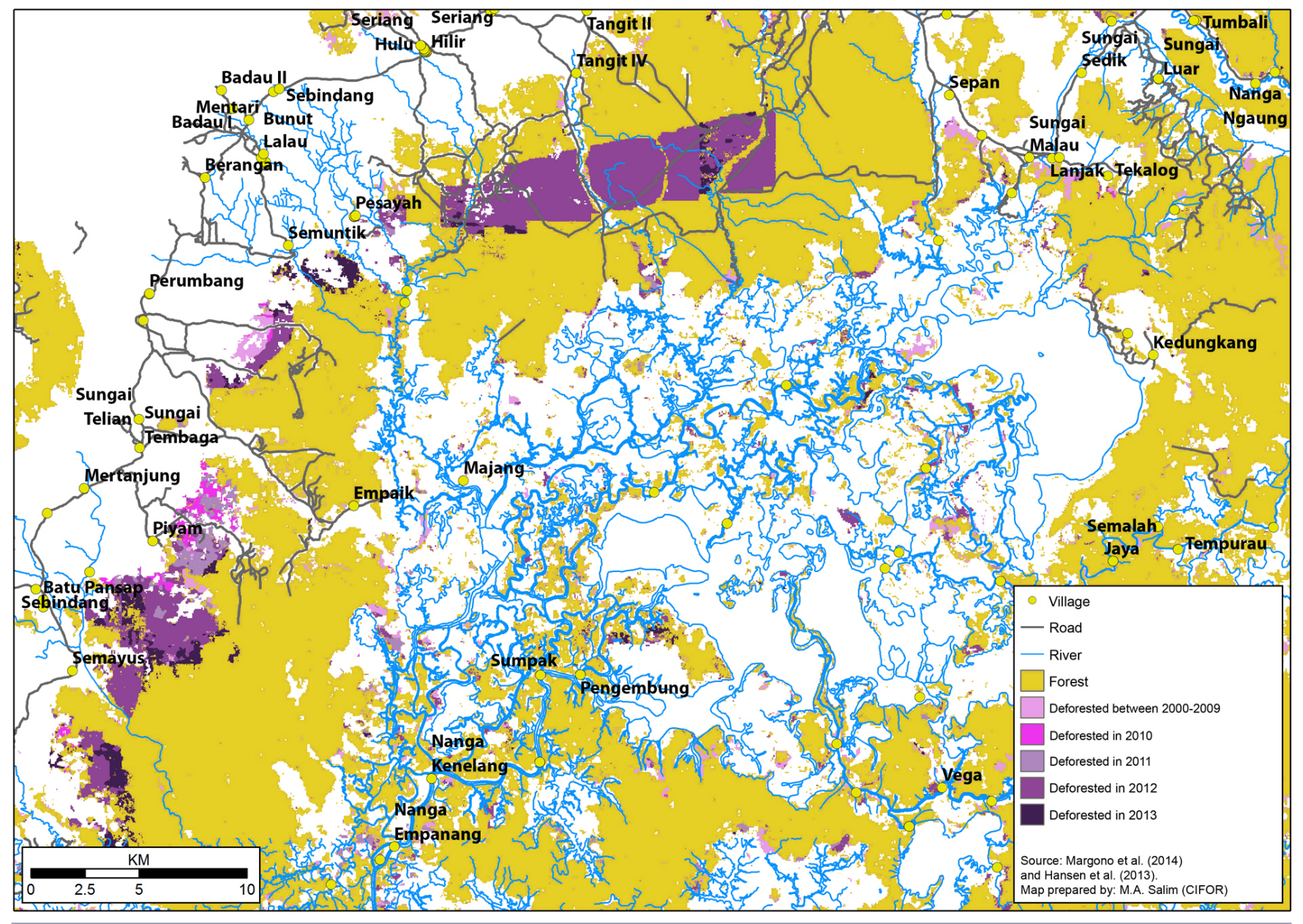

more than 3.5 million people. Danau Sentarum wetlands of more than $1,300 \mathrm{~km}^{2}$ is one of most important natural ecosystems in this district and regulates the water level of the Kapuas (Klepper 1994). The wetlands consist of 83 interconnected seasonal lakes, interspersed with freshwater swamp forests, peat swamp forests, and dry lowland forest on isolated hills (Giesen and Aglionby 2000). These ecosystems are also the habitats of many endemic species (Jeanes and Meijaard 2000), including the Bornean orangutan (Pongo pygmaeus pygmaeus; Russon et al. 2001) and the super-red Asian arowana fish or Asian bonytongue (Scleropages formosus), which is economically important but currently endangered in the wild (Kottelat and Widjanarti 2005). The wetlands was declared a National Park in 1999, but it took until 2006 before real authority was established in the so-called Danau Sentarum National Park (DSNP). Despite the importance of these ecosystems, $863 \mathrm{~km}^{2}$ of the district's forests were lost between 2001 and 2014, mainly because of oil palm expansion (Fig. 1).

In 2007, the Kapuas Hulu district government granted location permits (ijin lokasi) for the development of plantations to around 20 new oil palm companies for an area totalling $3000 \mathrm{~km}^{2}$. A location permit is the first in a series of permits that companies must apply for and obtain before being allowed to commence operations. Because companies are obliged to discuss land transfers and compensation with customary rights holders, their brokers do their utmost to secure the approval of village leaders, with tactics that include bribery (inducements) and trickery, using gaps in legislation and ambiguities and inconsistencies in institutional arrangements (see Yuliani et al. 2010 for details).

We focus our study on two Iban Dayak villages: Empakan (pseduonym) with a population of 117 people, living in 42 households and Riu (pseudonym) with a population of 145 people, divided over 51 households. The selection of these villages was based on the following criteria: located in the Danau Sentarum wetlands water catchment area; their forests being protected by local people in the face of logging and oil palm threats; the willingness of key stakeholders to participate in our research; and a minimal presence of other parties (NGOs) with the potential to bias answers given by respondents.

Empakan and Riu are located at the periphery of DSNP on the western and northeastern edge, respectively. Whereas neighboring villages decided to give up their land for conversion to oil palm plantations in 2007-2009, Empakan was the only community in 
the area that rejected oil palm companies. As a minority, the people of Empakan faced many challenges and criticism from other people in the area but stayed firm. The village of Riu was one amongst 30 other villages in the northeastern area of DSNP that rejected oil palm companies up until today. However, they made history in 2007 when customary leaders put the head of the subdistrict on trial and sanctioned him by customary leaders for marking family and communal properties for oil palm companies without approval from the local people.

The landscapes of both villages (kampung) comprise mosaics of hill, lowland, and peat swamp forests, seasonally flooded lakes, mixed agroforests, swidden fields, and cash crops orchards. Both communities apply traditional land use classifications and property rights to denote specific plots of land. Family property includes land under swidden cultivation, fallow, orchard, and mixed agroforest and bilik (compartment with a communal longhouse), which should all be maintained and passed on to one's descendants. Communal property comprises the longhouse (rumah panjai), forest reserves (rimba simpan), sacred groves (pulau) in various forms such as former longhouse sites (tembawai), graveyards (pendam), particular trees, stones or springs, communal forest and lake, and village fishing areas.

Traditional livelihood activities in the two communities consist of swidden rice and vegetable cultivation, traditional fishing, wildlife hunting, and collecting fruit and edible plants from the forests, mainly for subsistence. Swidden cultivation takes place on dryland (ladang) and on shallow swamps by the river (paya). In more permanent locations, they plant rubber and pepper for additional income.

They use a mixture of traditional knowledge and beliefs as guidance for these activities. Because rice is a central element in Iban life, many elements of traditional knowledge and beliefs involve rice (Sather 1994). For example, each year they select and preserve the best rice seeds to be planted next year, as a way to show respect to the ancestors who handed over those good seeds and to ensure sustainability of the resource. There are several types of local rice, the most common of which are pun, sangking, penyelapat, and pulut. Pun is considered sacred, believed to be the origin of all types of rice and the source of well-being. As a sacred type, pun is always planted first and at the center of the field thereby "protected," surrounded by sangking at the outer layer, then by other types.

Another example are the major traditional ceremonies: rice festivals (gawai) and earth praising ceremonies (bedarak). Gawai are organized collectively by Iban communities in order to celebrate the rice harvest. Bedarak are conducted at the beginning of the planting season, aimed at "feeding the earth" and seeking blessings on the farmland. In present-day practice, these traditions are blended with monotheistic religion (largely Catholic in our villages), so that people can be heard saying that the rice festival is held to elicit the blessings of God.

The Iban traditions also comprise beliefs, practices, and rituals that help build community and make sense of life. For instance, in cases of repeated misfortunes or sickness of community members, the Iban usually move to a new location to build a new long-house. The traditional leaders decide when and where to move. Their decisions are made after traditional rituals to seek advice from the ancestors and the spirits, therefore should be followed.

There are also differences between the two communities, especially with respect to economic and social activities outside traditional practices. The people of Empakan have diverse smallscale businesses and a wide social network beyond the village boundaries, primarily as a result of the village's strategic location on a shortcut between the northern and southern parts of the wetlands through the waterways, where many people pause to shop and chat in its small stores and cafés. The Empakan community used this situation for proactive networking with outsiders, and to acquire knowledge about new developments and opportunities.

The people of Riu have fewer alternatives for generating an income. They meet other people only when they go to the nearest town a few times a week to sell vegetables and buy groceries, but not for entering networks or acquiring new knowledge. None of the village's inhabitants have developed entrepreneurial activities, and in contrast to Empakan, many Riu villagers are involved in wage labor, especially construction work across the border in Malaysia.

\section{CONCEPTUAL FRAMEWORK AND METHODS}

The research questions of this paper are about the "why" of social action and about the capacity of the indigenous people to undertake such actions. This section describes the key concepts. Its purpose is not to initiate any new discussion but to arrive at a set of concepts broad yet clear enough to serve as a framework for analysis.

\section{Ex ante conceptual framework}

Figure 2 shows the conceptual framework the study commenced with to support effective data gathering. In line with Elster (1989) and De Groot (1992), the overall structure assumes that in order to act, people need the capacity to do so as well as having the motivation, and consider the perceived consequences of a decision in terms of the motivational criteria. If, for instance, prestige is a motivation, loss of prestige can be perceived as a consequence. The term perceived is important here because, as may well be imagined in our villages, oil palm corporations that approach villagers make many promises, and the degree to which these promises are believed may determine many of the community's decisions. Finally, decisions are depicted as being influenced by pressures (in our case, from logging and oil palm corporations), denoting actions that are not merely sidelines of the perceived consequences, but designed specifically to influence the decisions, such as bribery of some key persons, initiating rumors to undermine others, or issuing threats. On the top right of Figure 2, the final outcome is seen as being influenced by the first decision and by ongoing pressures.

Community capacity is the first of the detailed concepts in the framework that needs further elaboration. We emphasize community level because under Indonesian legislation such as Law No. 18/2004, which at present has been replaced by Law 39/2014 (Government of Indonesia 2014), an agreed compensation by the customary land rights holders is required. This law is part of what we have called contextual capacity, denoting any de facto capacity handed over to (or usurped from) the community by the state or other external agencies. 
Fig. 2. Conceptual framework.

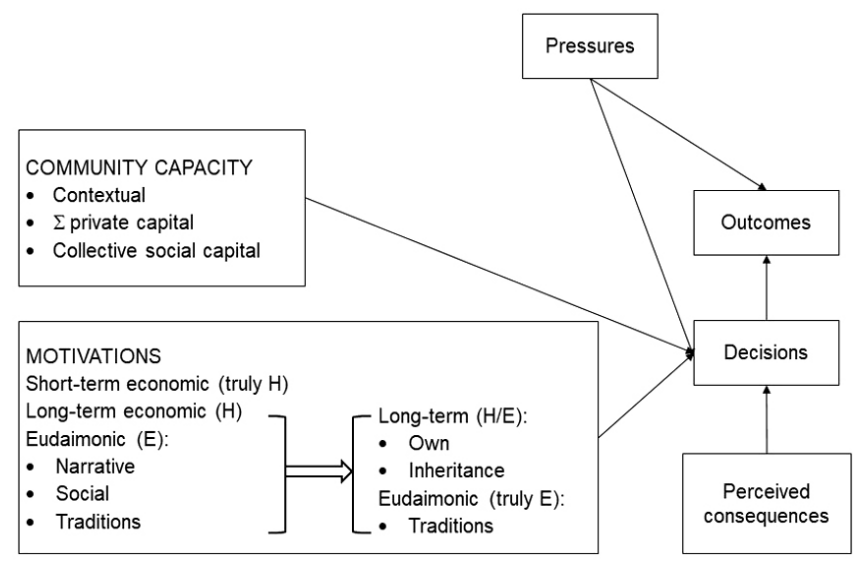

' $\mathrm{H}$ ' means hedonic; 'E' means eudaimonic. The large brackets and arrow depict the crossover from ex ante to ex post framing of motivations.

The next component is the sum total of private capacities individual community members may be willing to put to work at the community level. Following Bebbington (1999), such capacities may include economic capital but also knowledge or linkages with external powers "bridging social capital" (Coffé and Geys 2007, Putnam 2000) for the community. The final component of community capacity is collective social capital. Following De Groot and Tadepally (2008), this is not a sum total of individuals' social capital (sensu Bourdieu 1986), but a true system-level characteristic sensu Putnam (1995). In our field-level research, community capacity was made operational through variables such as wealth, knowledge, and connections; the willingness to make these available to contribute to communitylevel leadership; mutual trust and intensity of community relationships; and the maintenance of community-level institutions.

The concept we paid most attention to in our construction of the conceptual framework is motivations. Literature on human motivation is often contradictory, e.g., assuming a dominance of economic motives or taking a much broader view. These broader views include cultural, emotional, and affective factors that can play an important role when communities engage in care for their land. For example, Stern et al. (1999) explain the roles of valuebelief-norm theory; Ryan and Deci (2001) self-determination theory; Chan et al. (2016) and Arias-Arévalo et al. (2017) on the intrinsic, instrumental, and relational values; Colding and Folke (2001), Peterson (2014), and Yuliani et al. (2018) personal and cultural values such as resource and habitat taboos; Nightingale (2011) and Singh (2013, 2015) describe the transformative potentials of subjectivity and emotional reasons such as joy and life-affirming aspects in proconservation behavior and cooperation; while Berkes et al. (2014) developed guidelines for the analysis of social-ecological systems that emphasize the importance of motivation.

In our conceptual framework, we capture these different perspectives, as the classic Greek philosophers did, in terms of hedonic versus eudaimonic motivation. Hedonic motivation focuses on happiness through the avoidance of pain and the attainment of pleasure, quite in line with present day economic preferences/rationality and hedonic psychology (Kahneman et al. 1999). Noting that the pursuit of pleasure does not necessarily focus on immediate satisfaction only, the framework includes a longer-term hedonic perspective as well, e.g., such as saving or investing or, as in our villages, hoping for the arrival of infrastructure that facilitates village-level economic growth.

Eudaimonic motivations on the other hand express the human desire to live a complete, connected, and meaningful life (MacIntyre 1985, Ryan and Deci 2001), which is deeply different from desiring perpetual hedonic happiness (O'Neill 1992, 2002). The meaningful life (eudaimonia) is a practice-oriented ethical, social, cultural, and psychological concept (Annas 2002, May 2010, Badhwar 2014, Haybron 2016, Schwartz and Wrzesniewski 2016). It is a narrative concept because people desire and create a coherent, sense-making story of self and community. It is a social concept because people desire and act to make a difference in their community or in the world. It is a cultural concept because people intuit and learn that traditions and shared values help in making sense of life. Finally it is a psychological concept because contrary to common dualistic Western philosophical frames, eudaimonia is expressed in an intimate intertwining of thinking (ratio), feeling (affect, emotion), and action. As evident from Figure 2, we retained only the first three aspects of eudaimonia because these were the relevant ones in our case. Consequently, in the conceptual framework, we find short-term economics, longterm economics, and the three aspects of a meaningful life as the motivational categories designed to enable rich and balanced fieldwork results. During the fieldwork, the meaningful life concept was made operational through interview questions and discussions on connectedness with nature and community, ideas on the good life, and the sense-making role of traditions.

A last feature in Figure 2 is that within the motivational element, a somewhat shifted framing of the categories is present after the large bracket. This represents an ex post reformulation that resulted from the fieldwork, and will be discussed in the results section.

\section{Methods for data collection and analysis}

The main method we used was conversation with a purpose (Burgess 1984), i.e., semistructured, in-depth interviews in an informal setting, where issues of concern are raised in a natural sequence in accordance with the flow of conversation (see conversation topics in Table 1). To establish a time reference of the history, we used the life history technique (Atkinson 1998), referring to important family, social, political, or environmental events, such as long droughts, weddings, births, and presidencies.

In selecting participants, we used snowball sampling (Goodman 1961, Morgan 2008) until we reached a saturation point (Glaser and Strauss 1967), based on the following criteria for participants (adapted from Rubin and Rubin 2012): knowledgeable and experienced in the issues under study; representing a range of points of view (supporters, opponents, undecided) and groups (gender, age, wealth, origin); and demonstrating a willingness to talk. In total we interviewed 33 participants (17 in Empakan and 16 in Riu; 16 women and 17 men; 10 customary leaders and village chiefs, one of them a woman leader), sometimes several times. Later on we discarded data from three respondents who were only 12 years of age or younger at the time the oil palm discussions took place. 
Table 1. List of conversation topics.

\begin{tabular}{|c|c|}
\hline Conversation topics & Information probed \\
\hline $\begin{array}{l}\text { Activities and associated institutions when logging and oil palm } \\
\text { came }\end{array}$ & $\begin{array}{l}\text { Income generation etc. over time; } \\
\text { Norms and rules, e.g., traditional land-use systems and tenure, compliance; } \\
\text { Roles of leadership, knowledge, and information. }\end{array}$ \\
\hline Life histories & $\begin{array}{l}\text { Changes over time: livelihoods, surrounding environment and resources, } \\
\text { infrastructure, relationships (intra- and intercommunity; between community } \\
\text { and outsiders, e.g., the government, business people, and markets; between } \\
\text { community and natural resources, infrastructure; perceived causes of these } \\
\text { changes; } \\
\text { Life objectives, strategies, coping over time; } \\
\text { Roles of traditions in the community; } \\
\text { Meaningful elements of nature and land; } \\
\text { Formative experiences (childhood, spiritual, cultural, etc.); } \\
\text { What, finally, is the respondent's overall idea of the good life and a good future? }\end{array}$ \\
\hline Logging and oil palm & $\begin{array}{l}\text { Promises, pressures, and acts of logging and oil palm actors; } \\
\text { Individual and community responses; } \\
\text { Processes at the community level; } \\
\text { Perceived underlying factors, including the economic motivations and the } \\
\text { variables of community capacity. }\end{array}$ \\
\hline
\end{tabular}

In addition to the individual interviews, we conducted five focus group discussions (FGDs; Morgan 1997) and informal discussions. We had three FGDs in Riu and two in Empakan, with five to seven official participants. In practice the number of participants was higher because many villagers joined and enriched the discussions. The FGDs centered on issues of traditional land use systems, natural resources, incomegenerating activities, changes over time and major causes of logging and oil palm expansion, and roles of formal (state) and informal (customary) institutions. We did not limit the topics to the logging and oil palm because we wanted to understand the causal relations with other possible factors. During the FGDs, we used the participatory village sketch method (Pretty et al. 1995) as a tool to (i) visualize traditional land use and tenure systems including sacred groves, types of ownership (communal, family, or individual), and other important parts of the villages; (ii) document customary rules and institutions pertaining to these elements; and (iii) check the terms and language used.

Finally, informal discussions were shaped using moderate participation (DeWalt and DeWalt 2011). We joined villagers in their day-to-day activities, such as rubber tapping, fishing, informal gathering, and chatting in afternoons and evenings, and more formal village meetings. We listened carefully to their conversation to check for consistencies or inconsistencies between interviews and practice. Whenever the topics became relevant to the issues we studied, we asked clarification questions (except in formal village meetings where we purely observed).

Each interview and FGD took between two to four hours and used Indonesian and Iban languages. Data collection took place between May 2014 and December 2016, though we had been conducting fieldwork in the Danau Sentarum and Kapuas Hulu region already for more than a decade. All information gathered from the above methods was manually documented as verbatim records. This information was first put into narrative analysis, then further analyzed for emerging common themes that were linked to the localized sensitizing concepts and the oil palm discussion, using descriptive and value-coding techniques (Saldaña 2009) by one coder. All data were cross-checked and triangulated with field assistant before coded.

\section{RESULTS}

Our findings show that the communities' responses to logging and oil palm cultivation attempts were strongly driven by the interconnected factors of history and policies of land use, culture, and economic context, described at the beginning of each section.

\section{Logging, oil palm, and community responses}

\section{Logging}

The 1980s and 1990s were the golden era for the timber business in Indonesia, which was fully controlled by the central government, corporate conglomerates, and the military (Heri et al. 2010). The timber business was dominated by state companies and large-scale private concessions owned by Indonesian conglomerates. Having legal concessions, they are categorized as legal logging. At the time, there was no regulation that required compensation for the local people, even though the companies operated in their village territories. In Kapuas Hulu district, these concessions continued operating up until the late 1990s. Our respondents were quite aware that at the time, local people were nothing but powerless bystanders witnessing the onslaught on their ancestral lands without any say or recourse to compensation. The expression often used in their responses, "timber gone, people got nothing," is similar to Peluso's "Rich forests, poor people" (Peluso 1992).

In the late 1990s, many of these concessions licenses expired, while timber demand remained high. Meanwhile the early decentralization regulations still had many gaps, causing a power vacuum. This situation was used by new actors to their advantage. Between the late 1990s and 2005, illegal logging operators and more than 300 small-scale concessions had caused a new wave of deforestation (Budiarto et al. 2003, Yasmi et al. 2005, Hidayat 
2016). The illegal operators worked without permits from the Indonesian government and were financed by Malaysian timber barons (taukes) who paid local community groups to cut valuable timber in their village area (Eilenberg 2012). The other form, i.e., the small-scale concessions, were operating legally with permits from the district head under the new decentralization rules.

The logs were transported to Malaysia, therefore the first logging targets were the areas situated close to the country border and the main road to ease log transport. Empakan and Riu were relatively remote in that sense, being relatively far from the main road and the border. Thus in 2002, they were among the last communities to become involved in illegal logging. The strongest driving factors were a lively memory of the lack of compensation from the largescale 1980s/1990s operations, lack of government attention to facilitate the attainment of villagers' basic needs, and the intensive drought followed by several years of crop failure caused by the El Niño event in 1997-1998 that coincided with high consumer prices due to the Asian monetary crisis.

The Empakan community, however, had learned about bad experiences with some taukes from relatives in other villages. They therefore took careful steps. In village meetings, they developed their own strategies. Deals were to be made only with one tauke with a good track record of keeping his promises, paying a fair compensation, and listening to the people's demands. The demands were designed by the village customary leaders and comprised building a road, paying for the timber, compensating the workers, contributing to the village funds, and to $\log$ selectively, i.e., only cutting large trees of particular species and only from areas agreed by the community on the south-western side of the newly built road to protect their rimba simpan (forest reserve) and water sources (springs and streams), located on the other side of the road.

The idea to protect water sources originated from women. In the interviews, women also explained that they were actually worried about the safety of their husbands, sons, and male relatives because intensive timber cutting could involve high, even fatal risks. They raised their concern in the village meetings and among family members. Therefore many of Empakan men only cut trees for the first few months, then paid workers from other villages to do the job.

These illegal logging operations lasted until the end of 2004, when the Indonesian government took strict measures to stop all logging operations. The two years had delivered enough, however, for many Empakan villagers to invest in small-scale business, which were still operative in our fieldwork period.

While gaining a higher income, our respondents stated that the intensified logging caused timber scarcity. To build their own houses, good quality timber could only be found far away on hill slopes and in the forest reserve located approximately two to three kilometers from their settlement without road access. This strengthened the Empakan community to protect their forest reserve, not only preserving big trees but also allowing smaller ones to grow. They also collectively replanted previously burnt, bare land and logged-over areas with rubber, local fruit, and timber species. This form of traditional protection retained the forest as timber reserve for their next generation's subsistence uses. Moreover, another part was even left completely untouched, and labelled as sacred forest, in an effort to completely safeguard its protection.

The people of Riu had similar motives to get involved in logging: an economic one. One village leader stated the following:

\section{If the government had looked after its citizens and provided us basic facilities, and given us a fair share of the revenues from the legal logging concessions, we would not have been tempted to become involved [in the illegal logging business ]. We had to stand up for our rights. We lost our big timber, but we got money and clean water installations.}

However, they did not develop a well-thought set of demands that were handed over to the logging companies. They only asked for clean water installations and cash payments, without placing any restrictions on logging. Right after the clean water pipes were installed in 2003, externally driven logging operations took off until the end of 2004. Villagers in Riu took no collective action to replant logged-over areas, and the fact their inner forest was spared is only down to the 2005 logging ban. Proceeds were not invested in new businesses, but on buying motorcycles, generators, and electronic appliances.

\section{Oil palm}

Most of the people in Empakan and Riu became familiar with oil palm operation (cultivation, company-community partnership, employment, etc.) when they or their relatives were working on Malaysia's plantations. However they also learned from neighboring villages about the negative consequences of the oil palm operation in Indonesia, including trickery and broken promises from the companies. In its negotiations with two villages for example, one of the companies made significant promises but also insisted on acquiring land with tall forests including peat swamp forest containing large volumes of timber. The company began constructing an access road, but suddenly withdrew from the area after cutting down all the trees. The company's estate manager later admitted they had in fact been interested primarily in profits from timber (for more details see Wadley et al. 2000).

In 2007, other palm oil companies with Indonesian, Malaysian, and Thai investors, came to the district, looking for land and seeking people's approval. When the company's staff visited Empakan and Riu, they promised new infrastructure and high and immediate income from employment on construction projects and oil palm plantations and Nucleus Estates and Smallholders (NES) ${ }^{[1]}$ schemes, complemented by profitable out grower opportunities. Subsequently, the communities held meetings that involved all villagers to discuss their points of view. According to the respondents, very few community members were interested in the oil palm company's promises.

Customary leaders, village chiefs, and the majority of villagers had learnt from other villages that palm oil companies repeatedly broke their promises and were unreliable, and they were well aware that, contrary to logging, conversion to oil palm plantation is total and irreversible. Following a series of meetings that involved all men and women of the long-house, they decided to reject the oil palm proposals. We attempted to distinguish differences in reasoning between men and women but we found no major differences. Reasons quoted by men and women respondents were similar, i.e., to maintain ownership and control over communal 
land including forests and sacred groves, family and individual land, to maintain sustainability, and ensure intra- and intergenerational access to timber, clean water sources, and other natural resources. Specifically for Empakan, respondents also noted they already had reliable and operative sources of income, therefore they were not interested with the oil palm offers.

Respondents reported no pressures from the oil palm company before the first village decisions were made. Later, however, the company focused on influential individuals such as customary leaders and administrative leaders, offering them cash incentives and other gifts on condition they would try to convince other community members to accept oil palm development. The company also promised them employment and partnerships, and even took them by aeroplane to visit an oil palm plantation in Sumatra that showed wealthy farmers. The village leaders were prevented from actually talking with these farmers, however. The company also attempted to paint a negative image of proenvironment NGOs, so the communities would resist such NGOs if they ever came to their regions. All company efforts failed however, and the communities remained consistent in their rejection. Village elites displayed a strong sense of commitment and social responsibility as reflected in the interviews, with one respected elder in Riu saying, "We'd rather live with economic limitations than surrender our land for oil palm."

When the village elites proved uninterested, the company turned its attention to the camat (subdistrict head). Subsequently, the camat earmarked lands in Riu and other communities for oil palm plantations with no prior information or negotiation. In a surprising move, Iban customary leaders then filed a lawsuit and sanctions against the camat. This was the first time in Kapuas Hulu's history that a camat representing formal institutions had been taken to court by customary leaders representing informal institutions. After more than a year of failed attempts, the company finally gave up on Empakan and Riu, but continued promoting oil palm development in other villages.

\section{Explanatory factors}

\section{Reframing the framework}

During fieldwork, the ex ante framework shown in Figure 2 served its purpose well by focusing discussions on issues that mattered. At the same time, however, we found the framework could have performed better if it were phrased slightly differently, particularly in the area of hedonic/eudaimonic motivations. It turned out, for instance, that long-term motivations, conceptualized ex ante as a primarily hedonic (economic) issue, were strongly associated with the idea of inheritance and formulated in a eudaimonic manner, where a good life is one that leaves the basics for a good life to descendants. However, these basics, in turn, were seen mainly in economic terms, e.g., a healthy forest, a viable shop or arowana farm, good gardens, and rice land. In the ex post framework, therefore, long-term motivations are taken up as a mixed eudaimonic/hedonic concept, associated primarily with inheritance.

In the ex ante eudaimonic motivations, the narrative aspect did not come out with any emphasis. The struggle between perpetual consumption (hedonism) and the coherence of one's life story may currently be a more Western than Indonesian rural occupation. Or possibly, good life narratives were already summarized under the respondents' inheritance idea. We dropped the concept from the eudaimonic motivations, arriving at the ex post classification of Figure 2, representing our current best representation of fieldwork concepts in our case study.

\section{Community capacity}

The fact that both communities were able to resist the oil palm powers shows that obviously, they had the capacity to do so. For both of them, the decentralization law, specifying that village approval was necessary for oil palm expansion, was an essential element of this capacity. However, differences between the villages were also apparent. In Empakan, capacities were striking. On the private level, many households had relatively high and resilient incomes from land-based and entrepreneurial activities as well as private social capital, and many were willing to put these to work for-or at least refrain from using them against - the majority decision. On the level of collective social capital, the community could avail of coherent and respected leadership and welldeveloped bonds of trust and collaboration, e.g., in the maintenance of its autonomy and traditions. As one community member said, "Relations among community members are good, and we always share information or ideas. In arowana farming, for example, successful villagers motivate others to replicate them and offer help in various forms to get them started." According to another respondent, "When there is new program or aid from outside, our leaders organize community meetings to discuss how to proceed, comparing risks and benefits. They are transparent so we trust them."

The situation in Riu was different; households were less affluent, were more involved in wage labor rather than independent entrepreneurship as in Empakan, and were much less connected to sources of influence and information. At the collective level, leaders in Riu were not as transparent, creative, or tactful as those in Empakan. They could not have held out against the logging powers on their own. As Riu villagers said, "The logging investor met with elders several times and agreed to provide the water installations. We did not know what else they discussed, but we did not assign any particular area or type of tree [species] to log. The logging stopped because the government chased and arrested logging operators."

The village held out effectively against oil palm, because its contextual community capacity was strongly reinforced by the village joining some 30 other villages in 2007-2009 in acting collectively against the conversion of customary land for oil palm plantations. The same group initiated the trial against the camat, mentioned above. The forest in Riu survived under this collective capacity.

\section{Motivational factors}

As we have seen, the decisions to become involved in logging in the early 2000 s were driven primarily by economic motives, and were reinforced by challenging situations caused by the El Niño event. In Empakan, however, long-term considerations were held firmly in mind, putting community capacity to work in negotiations over selective logging and sparing selected areas, and later in collective replanting action. The mixed hedonic/ eudaimonic inheritance motive is in evidence here, with one respondent saying, "The elders always remind us our territory is an inheritance, so we must keep it safe for our descendants. By being united and helping each other, we have good things (sources of income, land, natural resources) to pass on to them." 
Economic motivations were also present in the case of oil palm. When the oil palm company made an appearance in 2007, the villagers' livelihoods had already improved and their short-term concerns over meeting basic needs were over. This allowed economic argumentation to focus less on short-term gain (wage labor income, etc.) and more on the long term and safeguarding current sources of income, many of which were environmentbased. The oil palm development implied total land conversion, and as one villager said, "Logging does not take over our land, but oil palm does." Consequently, economic motivations did not speak overwhelmingly for oil palm. As one respondent put it, "These businesses (arowana farms, pepper gardens, etc.) have been made possible by the good environment around us. [They would be] impossible if we were surrounded by oil palms. Oil palm will not make us richer."

As the framework in Figure 2 suggests, long-term economic thinking was mixed with inheritance notions. A respondent in Empakan said: "The most important thing for us is to hand over a good inheritance to our descendants: land for rice and cashcrops cultivation, timber to build their own houses, clean water, and effective income sources. Those good things would perish if we let the oil palm take over our village."

Of the more purely eudaimonic motivations, the social desire to make a positive difference in the community (and refrain from making a negative one) is evident in quotations such as this one from the former chief of Empakan, "When my [small-scale] business started to grow, I offered relatives and neighbors to join, or encouraged them to develop the same business. By doing so, we could be successful together. It is not good to achieve success alone, while others stay poor."

Our interviewees often mentioned traditional beliefs and belief in God. For them, the two went together. They were proud of their traditions and showed a deep belief in God. We encountered the belief in tradition, including a deep sense of being embedded in nature, in the desire to protect communal property such as sacred groves, the forest reserve, and lake reserve, and in annual rituals, such as gawai and bedarak explained earlier. Monotheistic concepts are often referred to as well, however, e.g., by the former chief of Empakan saying, "Taking advantage [by becoming a broker for the oil palm company] and therewith sacrificing others is a sin. We are afraid of God. We obey God's will and we do not want to be punished by God. We don't want our descendants to have a difficult life or to be cursed because of our sins." This belief in tradition and belief in God are also good examples of pure eudaimonic motivation: the desire to live meaningful, embedded life.

\section{DISCUSSION AND CONCLUSION}

Kalimantan is a battleground where structural, large-scale drivers of land use change, logging and oil palm expansion in particular, meet with local cultures embedded in communities who struggle to restore traditional communal rights over natural resources and land. In this paper, we have seen that a framework that includes both capacity and motivation to act served to help understand why two communities in Kalimantan could and did negotiate effectively with logging companies and rejected oil palm plantations taking over their land. Community capacities, e.g., wealth, connections, information, and the ability to work together, clearly differed between the communities, with one only being able to defend itself against oil palm expansion under a supra-local umbrella. Motivations were a mixture of (i) short-term economic arguments, e.g., gain from log sales or wage incomes, (ii) long-term perspectives, and (iii) eudaimonic aspects, i.e., the desire to live a meaningful life, associated with meaningful bonds with community and earth, inter alia, expressed in local traditions. The long-term perspectives were partly economic, e.g., focusing on new infrastructure, but also had a strong eudaimonic tinge, emphasizing bonds with future generations through inheritance.

A limitation in our method is that we did not include communities that have accepted oil palm companies to convert their land into plantations. We do not know, therefore, whether the fact that most communities in Kalimantan give in to structural pressures is caused by failing capacities, by different motivations, or a mixture of these (see for instance Elster 1989). Further comparative research is needed to investigate this issue.

Nevertheless, our investigation enriches the literature on land use change and Kalimantan in a variety of ways. First of all, description and analysis of successful resistance against logging and oil palm is rare, standing out against the mainstream impression that communities are still powerless or unwilling to resist the short-term economic lures (Rist et al. 2010, Levang et al. 2016). Another contrast is that Wadley et al. (1997:258) found that during their research period, "some [Iban] respondents felt that observing traditional taboos was a sign of cultural backwardness." We, however, found that all our respondents were proud of their culture. This may reflect a change in the ideology of the central government, which tuned down its strong emphasis on Western modernity in the early 2000 s.

The paper also enriches a more theoretical debate. To begin with, it is striking that contrary to standard economics, people did not unify short-term and long-term motivations into a single measure using a discount rate. They may do so (as we all do, basically) when comparing consumption options differing on a relatively short timeframe (say today versus next year), but not when it comes to the real future of one's own and community life as a whole, i.e., sustainability. This contrasts with the persistent belief among economists that discounting the future is universal, allied to the belief that all human desire is hedonic (De Groot 1992).

This finding illustrates the effectiveness of a comprehensive framework. As a general rule, research working in a merely economic framework will only uncover economic issues and motivations, and the same tunnelling effect will take place for research working in a strictly cultural, political-ecologic, or capacity (empowerment) paradigm (Vayda and Walters 1999). Of course we cannot prove that our hedonic/eudaimonic differentiation is the best or only way to generate a more integrative framework, but it did elucidate crucial aspects that otherwise would have remained underexposed.

On a more speculative note, we might consider that our insight could be further deepened by concepts put forward by the capability approach, developed by Sen (1999) and Nussbaum and Sen (1993). The capability approach digs deeper than just the availability of commodities and the capacity to use them, giving central place to, in Sen's words, "the freedom to function." However, since the capability approach is focused on individual functioning, any application on communities such as the ones we 
have encountered here needs to be enriched by community-level concepts. At this point, the community-level environmental justice idea suggested by Schlosberg and Carruthers (2010) may be of great relevance.

Like the capability approach, environmental justice approaches often emphasize individual-level phenomena, e.g., in terms of distributional justice. Schlosberg and Carruthers (2010), however, argue for the inclusion of collective aspects such as the functioning, recognition, and autonomy of communities. So doing, Schlosberg and Carruthers (2010) also integrate the capability approach in their environmental justice framework. This enriched environmental justice model promises to be valuable to the hedonic/eudaimonic framework too, in particular because it can deepen the understanding of eudaimonic and longterm hedonic motivations, strongly resonating as these do with community values, traditions, and practice.

${ }^{[1]}$ The Nucleus Estates and Smallholders (NES) or Perkebunan Inti Rakyat (PIR) scheme began in 1970s with financial support from the World Bank, aimed as a cooperative program between the plantation company (called Nucleus), and the smallholders (plasma). According to the Minister of Agriculture Decree no. $98 / 2013$, companies should allocate $20 \%$ of the plantation area for the NES scheme. Companies should also build the capacity of smallholders to develop and manage their plantations with benefit-sharing mechanisms, until they can operate independently. However, as reported by McCarthy et al. (2012:533), "large-scale violations continue despite codes of conduct and legal innovations that provide for elements of 'free, prior and informed consent'."

Responses to this article can be read online at: http://www.ecologyandsociety.org/issues/responses. php/10640

\section{Acknowledgments:}

The study was made possible by the Institute for Science in Society, Faculty of Science, Radboud University Nijmegen; the Center for International Forestry Research (CIFOR); De Koninklijke Nederlandse Akademie van Wetenschappen (KNAWIThe Royal Netherlands Academy of Arts and Sciences); The Indonesian Forest and Environmental Research, Development and Innovation Agency (FOERDIA); and USAID. We express our deepest gratitude to Prof. Wouter de Groot. We also specifically thank all the community members in our research locations, anonymous reviewers, Carol J. Pierce Colfer, Prof. M. N. C. Aarts, Prof. Dr. H. A. E. Zwart, Prof. A. J. M. Smits, Lizette Donders, Vera Jansen, Hilde van Bergen, Moira Moeliono, Amy Ickowitz, Christine Padoch, Wiwit Siswarini, Juniarta Panjaitan, Gideon Suharyanto, Deki Hardeki, Agus Djoko Ismanto, Ombo Satjapradja, Iman Santoso, and Prof. Yunita T. Winarto.

\section{LITERATURE CITED}

Annas, J. 2002. Should virtue make you happy? Apeiron 35 (4):1-20. http://dx.doi.org/10.1515/APEIRON.2002.35.4.1
Arias-Arévalo, P., B. Martín-López, and E. Gómez-Baggethun. 2017. Exploring intrinsic, instrumental, and relational values for sustainable management of social-ecological systems. Ecology and Society 22(4):43. http://dx.doi.org/10.5751/ES-09812-220443

Atkinson, R. 1998. The life story interview. Qualitative Research Methods Series 44. SAGE, Thousand Oaks, California, USA. http://dx.doi.org/10.4135/9781412986205

Badhwar, N. K. 2014. Well-being: happiness in a worthwhile life. Oxford University Press, Oxford, UK. http://dx.doi.org/10.1093/ acprof:0so/9780195323276.001.0001

Barr, C., I. A. P. Resosudarmo, J. McCarthy, and A. Dermawan. 2006. Forest and decentralization in Indonesia: an overview. Pages 1-17 in C. Barr, I. A. P. Resosudarmo, A. Dermawan, J. McCarthy, M. Moeliono, and B. Setiono, editors. Decentralization of forest administration in Indonesia: implications for forest sustainability, economic development and community livelihoods. CIFOR, Bogor, Indonesia.

Bebbington, A. 1999. Capitals and capabilities: a framework for analyzing peasant viability, rural livelihoods and poverty. World Development 27:2021-2044. http://dx.doi.org/10.1016/S0305-750X (99)00104-7

Berkes, F., M. A. Ibarra, D. Armitage, T. Charles, L. Loucks, M. Makino, A. Satria, C. Seixas, and J. Abraham. 2014. Guidelines for the analysis of social-ecological systems. Community Conservation Research Network Working Group on SocialEcological Systems and Community Resilience, Halifax, Nova Scotia, Canada.

Bourdieu, P. 1986. The forms of capital. Pages 241-258 in J. G. Richardson, editor. The handbook of theory and research for the sociology of education. Greenwood, Westport, Connecticut, USA.

Budiarto, T., A. Setyarso, E. P. Slamet, and G. Anshari. 2003. Illegal logging, livelihood security and conflict: the case of West Kalimantan. EDSP Working Paper No. 4. Adelphi-Research, Berlin, Germany.

Burgess, R. G. 1984. In the field: an introduction to field research. Allen \& Unwin, London, UK. http://dx.doi.org/10.4324/9780203418161

Chan, K. M. A., P. Balvanera, K. Benessaiah, M. Chapman, S. Díaz, E. Gómez-Baggethun, R. Goul, N. Hannahs, K. Jax, S. Klain, G. W. Luck, B. Martín-López, B. Muraca, B. Norton, K. Ott, U. Pascual, T. Satterfield, M. Tadaki, J. Taggart, and N. Turner. 2016. Why protect nature? Rethinking values and the environment. Proceedings of the National Academy of Sciences 113(6):1462-1465. http://dx.doi.org/10.1073/pnas.1525002113

Coffé, H., and B. Geys. 2007. Toward an empirical characterization of bridging and bonding social capital. Nonprofit and Voluntary Sector Quarterly 36(1):121-139. http:// dx.doi.org/10.1177/0899764006293181

Colding, J., and C. Folke. 2001. Social taboos: "invisible" systems of local resource management and biological conservation. Ecological Applications 11:584-600.

De Groot, W. T. 1992. Environmental science theory: concepts and methods in a one-world, problem-oriented paradigm. Elsevier Science, Amsterdam, The Netherlands. 
De Groot, W. T., and H. Tadepally. 2008. Community action for environmental restoration: a case study on collective social capital in India. Environment, Development and Sustainability 10:519-536. http://dx.doi.org/10.1007/s10668-006-9078-8

De Jong, E. B. P., L. Knippenberg, and L. Bakker. 2017. New frontiers: an enriched perspective on extraction frontiers in Indonesia. Critical Asian Studies 49(3):330-348. http://dx.doi. org/10.1080/14672715.2017.1333267

DeWalt, K. M. D, and B. R. DeWalt. 2011. Participant observation: a guide for fieldworkers. Rowman, Altamira, Lanham, Maryland, USA.

Eilenberg, M. 2012. The confession of a timber baron: patterns of patronage on the Indonesian-Malaysian border. Identities: Global Studies in Culture and Power 19(2):149-167. http://dx.doi. org/10.1080/1070289X.2012.672841

Elster, J. 1989. Nuts and bolts of the social sciences. Cambridge University Press, Cambridge, UK. http://dx.doi.org/10.1017/ CBO9780511812255

Forest Watch Indonesia (FWI). 2011. Potret keadaan hutan Indonesia periode 2000-2009 [ The portrait of the Indonesian forest 2000-2009]. FWI, Bogor, Indonesia.

Giesen, W., and J. Aglionby. 2000. Introduction to Danau Sentarum National Park, West Kalimantan, Indonesia. Borneo Research Bulletin 31:5-28.

Glaser, B., and A. Strauss. 1967. Discovery of grounded theory: strategies for qualitative research. Routledge, New York, New York, USA. http://dx.doi.org/10.4324/9780203793206

Goodman, L. A. 1961. Snowball sampling. Annals of Mathematical Statistics 32(1):148-170. http://dx.doi.org/10.1214/ aoms/1177705148

Government of Indonesia. 1999. Government Regulation no. $6 / 1999$ on Forestry Enterprises and the Extraction of Forest Products in Areas Designated as Production Forest [Peraturan Pemerintah no. $6 / 1999$ tentang Pengusahaan Hutan dan Pemungutan Hutan pada Hutan Produksi]. Government of Indonesia, Jakarta, Indonesia.

Government of Indonesia. 2004. Law (Undang-Undang) no. 18/2004 on Plantation. Government of Indonesia, Jakarta, Indonesia.

Government of Indonesia. 2014. Law (Undang-Undang) no. $39 / 2014$ on Plantation. Government of Indonesia, Jakarta, Indonesia.

Hansen, M. C., P. V. Potapov, R. Moore, M. Hancher, S. A. Turubanova, A. Tyukavina, D. Thau, S. V. Stehman, S. J. Goetz, T. R. Loveland, et al. 2013. High-resolution global maps of 21stcentury forest cover change. Science 342:850-853. http://dx.doi. org/10.1126/science. 1244693

Haybron, D. M. 2016. The philosophical basis of eudaimonic psychology. Pages 27-53 in J. Vittersø, editor. Handbook of eudaimonic well-being. International handbooks of quality-oflife. Springer International, Switzerland. http://dx.doi. org/10.1007/978-3-319-42445-3 2
Heri, V., E. L. Yuliani, and Y. Indriatmoko. 2010. Interacting threats and challenges in managing Danau Sentarum. Borneo Research Bulletin 41:74-100.

Hidayat, H. 2016. Forest resources management in Indonesia (1968-2004): a political ecology approach. Springer, Singapore. http://dx.doi.org/10.1007/978-981-287-745-1

Jeanes, K., and E. Meijaard. 2000. Danau Sentarum's wildlife. Part 1: biodiversity value and global importance. Borneo Research Bulletin 31:150-229.

Kahneman, D., E. Diener, and N. Schwarz. 1999. Well-being: the foundations of hedonic psychology. Russell Sage Foundation, New York, New York, USA.

Kapuas Hulu Statistics. 2017. Kapuas Hulu Regency in Figures. Kapuas Hulu Statistics, Putussibau, Indonesia.

Kelly, A. B., and N. L. Peluso. 2015. Frontiers of commodification: state lands and their formalization. Society \& Natural Resources 28(5):473-495. http://dx.doi.org/10.1080/089$\underline{41920.2015 .1014602}$

Klepper, O. 1994. A hydrological model of the upper Kapuas River and the Kapuas lakes. Consultancy report for Asian Wetland Bureau/PHPA, for the UK-Indonesia Tropical Forest Management Project, Sub-project 5 Conservation. Directorate General of Forest Protection and Nature Conservation: Asian Wetland Bureau, Bogor, Indonesia

Kottelat, M., and E. Widjanarti. 2005. The fishes of Danau Sentarum National Park and the Kapuas lakes area, Kalimantan Barat, Indonesia. Raffles Bulletin of Zoology Supplement 13:139-173.

Levang, P., W. P. Riva, and M. G. Orth. 2016. Oil palm plantations and conflict in Indonesia: evidence from West Kalimantan. Pages 283-300 in R. Cramb and J. F. McCarthy, editors. The oil palm complex: smallholders, agribusiness and the state in Indonesia and Malaysia. NUS Press, Singapore. http://dx.doi.org/10.2307/j. ctv1xz0km.13

MacIntyre, A. 1985. After virtue: a study in moral theory. Second edition. Duckworth, London, UK.

Margono, B. A., P. V. Potapov, S. Turubanova, F. Stolle, and M. C. Hansen. 2014. Primary forest cover loss in Indonesia over 2000-2012. Nature Climate Change 4:730-735. http://dx.doi. org/10.1038/nclimate2277

May, H. 2010. Aristotle's ethics: moral development and human nature. Continuum International, London, UK.

McCarthy, J. F., and R. A. Cramb. 2009. Policy narratives, landholder engagement, and oil palm expansion on the Malaysian and Indonesian frontiers. Geographical Journal 175(2):112-123. http://dx.doi.org/10.1111/j.1475-4959.2009.00322.x

McCarthy, J. F., J. A. C. Vel, and S. Affif. 2012. Trajectories of land acquisition and enclosure: development schemes, virtual land grabs, and green acquisitions in Indonesia's Outer Islands. Journal of Peasant Studies 39(2):521-549. http://dx.doi. org/10.1080/03066150.2012.671768

Ministry of Agriculture of Indonesia. 2013. Agriculture Ministerial Regulation no. 98/2013 on Plantation Business 
Licensing Guidelines [Peraturan Menteri Pertanian tentang no. 98/2013 tentang Pedoman Perizinan Usaha Perkebunan]. Government of Indonesia, Jakarta, Indonesia.

Morgan, D. L. 1997. Focus groups as qualitative research. SAGE, Thousand Oaks, California, USA. http://dx.doi. org/10.4135/9781412984287

Morgan, D. L. 2008. Snowball sampling. Pages 816-817 in L. Given, editor. The SAGE Encyclopedia of Qualitative Research Methods. SAGE, Thousand Oaks, California, USA.

Nightingale, A. J. 2011. Beyond design principles: subjectivity, emotion and the (ir)rational commons. Society \& Natural Resources 24(2):119-132. http://dx.doi.org/10.1080/08941920903278160

Nussbaum, M. C., and A. Sen. 1993. The quality of life. Clarendon, Oxford, UK. http://dx.doi.org/10.1093/0198287976.001.0001

Obidzinski, K. 2005. Illegal logging in Indonesia: myth and reality. Pages 193-206 in B. P. Resosudarmo, editor. The politics and economics of Indonesia's natural resources. The Institute of Southeast Asian Studies (ISEAS) Press, Singapore. http://dx.doi. org/10.1355/9789812305497-018

O'Neill, J. 1992. The varieties of intrinsic value. Monist 75:119-137. http://dx.doi.org/10.5840/monist19927527

O'Neill, J. 2002. Ecology, policy and politics: human well-being and the natural world. Routledge, London, UK. http://dx.doi. org/10.4324/9780203416570

Peluso, N. L. 1992. Rich forests, poor people: resource control and resistance in Java. University of California Press, Berkeley, California, USA. http://dx.doi.org/10.1525/california/9780520073777.001 .0001

Peterson, N. D. 2014. Breaking the bounds of rationality: values, relationships, and decision-making in Mexican fishing communities. Conservation and Society 12(3):245-256. http://dx. doi.org/10.4103/0972-4923.145135

Pretty, J. N., I. Guijt, I. Scoones, and J. Thompson. 1995. A trainers' guide for participatory learning and action. IIED Participatory Methodology Series. International Institute for Environment and Development, London, UK.

Putnam, R. D. 1995. Bowling alone: America's declining social capital. Journal of Democracy 6:65-78. http://dx.doi.org/10.1353/ jod.1995.0002

Putnam, R. 2000. Bowling alone: collapse and revival of American community. Simon and Schuster, New York, New York, USA. http://dx.doi.org/10.1145/358916.361990

Rist, L., L. Feintrenie, and P. Levang. 2010. The livelihood impacts of oil palm: smallholders in Indonesia. Biodiversity and Conservation 19(4):1009-1024. http://dx.doi.org/10.1007/s10531-010-9815$\underline{\mathrm{Z}}$

Rubin, H. J., and I. S. Rubin. 2012. Qualitative interviewing: the art of hearing data. SAGE, Thousands Oaks, California, USA.

Rudel, T., and J. Roper. 1997. The paths to rain forest destruction: crossnational patterns of tropical deforestation, 1975-1990. World Development 25(1):53-65. http://dx.doi.org/10.1016/ $\underline{\mathrm{S} 0305-750 \mathrm{X}(96) 00086-1}$
Russon, A. E., A. Erman, and R. Dennis. 2001. The population and distribution of orangutans (Pongo pygmaeus pygmaeus) in and around the Danau Sentarum Wildlife Reserve, West Kalimantan, Indonesia. Biological Conservation 97:21-28. http:// dx.doi.org/10.1016/S0006-3207(00)00087-2

Ryan, R. M., and E. L. Deci. 2001. On happiness and human potentials: a review of research on hedonic and eudaimonic wellbeing. Annual Review of Psychology 52:141-166. http://dx.doi. org/10.1146/annurev.psych.52.1.141

Saldaña, J. 2009. The coding manual for qualitative researchers. SAGE, London, UK.

Sather, C. 1994. The one-sided one: Iban rice myths, agricultural ritual and notions of ancestry. Pages 119-150 in A. R. Walker, editor. Rice in southeast Asian myth and ritual. Contributions to southeast Asian Ethnography No. 10. Ohio State University, Columbus, Ohio, USA.

Schlosberg, D., and D. Carruthers. 2010. Indigenous struggles, environmental justice, and community capabilities. Global Environmental Politics 10(4):12-35. http://dx.doi.org/10.1162/ GLEP_a_00029

Schmink, M., and C. Wood. 1992. Contested frontiers in Amazonia. Colombia University Press, New York, New York, USA.

Schwartz, B., and A. Wrzesniewski. 2016. Internal motivation, instrumental motivation, and eudaimonia. Pages 123-134 in J. Vittersø, editor. Handbook of eudaimonic well-being. International handbooks of quality-of-life. Springer International, Switzerland. http://dx.doi.org/10.1007/978-3-319-42445-3 8

Sen, A. 1999. Development as freedom. Alfred A. Knopf, New York, New York, USA.

Sheil, D., A. Casson, E. Meijaard, M. van Nordwijk, J. Gaskell, J. Sunderland-Groves, K. Wertz, and M. Kanninen. 2009. The impacts and opportunities of oil palm in Southeast Asia: What do we know and what do we need to know? Occasional Paper 51. CIFOR, Bogor, Indonesia.

Singh, N. M. 2013. The affective labor of growing forests and the becoming of environmental subjects: rethinking environmentality in Odisha, India. Geoforum 47:189-198. http://dx.doi. org/10.1016/j.geoforum.2013.01.010

Singh, N. M. 2015. Payments for ecosystem services and the gift paradigm: sharing the burden and joy of environmental care. Ecological Economics 117:53-61. http://dx.doi.org/10.1016/j. ecolecon.2015.06.011

Smith, J., K. Obidzinski, Subarudi, and I. Suramenggala. 2003. Illegal logging, collusive corruption and fragmented governments in Kalimantan, Indonesia. International Forestry Review 5 (3):293-302. http://dx.doi.org/10.1505/IFOR.5.3.293.19138

Stern, P. C., T. Dietz, T. Abel, G. A. Guagano, and L. Kalof. 1999. A value-belief-norm theory of support for social movements: the case of environmentalism. Human Ecology Review 6(2):81-96.

Vayda, A. P., and B. B. Walters. 1999. Against political ecology. Human Ecology 27(1):167-179. http://dx.doi.org/10.1023/ A:1018713502547 
Wadley, R. L., C. J. P. Colfer, and I. G. Hood. 1997. Hunting primates and managing forests: the case of Iban forest farmers in Indonesian Borneo. Human Ecology 25(2):243-271. http://dx.doi. org/10.1023/A:1021926206649

Wadley, R. L., R. A. Dennis, E. Meijaard, A. Erman, H. Valentinus, and W. Giesen. 2000. After the conservation project: Danau Sentarum National Park and its vicinity - conditions and prospects. Borneo Research Bulletin 31:385-401.

Wadley, R. L., and M. Eilenberg. 2005. Autonomy, identity, and 'illegal' logging in the borderland of West Kalimantan, Indonesia. Asia Pacific Journal of Anthropology 6(1):19-34. http://dx.doi. org/10.1080/14442210500074853

Yasmi, Y., G. Z. Anshari, S. Alqadrie, T. Budiarto, Ngusmanto, E. Abidin, H. Komarudin, S. McGrath, Zulkifli, and Afifudin. 2005. The complexities of managing forest resources in postdecentralization Indonesia: a case study from Sintang district, West Kalimantan. Case studies on decentralization and forests in Indonesia No. 10. CIFOR, Bogor, Indonesia.

Yuliani, E. L., H. Adnan, R. Achdiawan, D. Bakara, V. Heri, J. Sammy, M. A. Salim, and T. Sunderland. 2018. The roles of traditional knowledge systems in orang-utan Pongo spp. and forest conservation: a case study of Danau Sentarum, West Kalimantan, Indonesia. Oryx 52:156-165. http://dx.doi. org/10.1017/S0030605316000636

Yuliani, E. L., Y. Indriatmoko, M. A. Salim, I. Z. Farid, M. Muhajir, L. B. Prasetyo, and V. Heri. 2010. Biofuel policies and their impacts on local people and biodiversity: a case study in Danau Sentarum. Borneo Research Bulletin 41:109-144. 